\title{
INTRODUCTION TO SYMPOSIUM ON THE IMMUNITY OF STATE OFFICIALS
}

\author{
Ingrid B. Wuerth*
}

The International Law Commission (ILC) has taken up the controversial and important topic of the immunity of state officials from the national criminal jurisdiction of another state. Added to the Commission's agenda in 2007, the topic has been analyzed by two special rapporteurs in seven different reports by the end of $2015 .{ }^{1}$ For readers interested in the short version of the state-of-play, the draft articles preliminarily adopted by the ILC through the summer of 2015 are reproduced at the end of this introduction. The symposium includes contributions from three experts who have each written extensively about immunity: William Dodge, ${ }^{2}$ Chimène Keitner, ${ }^{3}$ and Roger O'Keefe. ${ }^{4}$ The authors offer three distinctive perspectives on the work already completed (in draft form) by the ILC and on future issues, including the question of exceptions to immunity for conduct which violates international human rights law.

For readers interested in a slightly longer introduction to the ILC's work on this topic, read on. The first special rapporteur, Roman A. Kolodkin (Russia), submitted three reports which examined (among other materials) State practice and the opinions of the International Court of Justice, generally taking a broad view of immunity and a narrow of view of exceptions. The second special rapporteur, Concepción Escobar Hernández (Spain) was appointed in 2012. She has prepared four reports, the first of which suggested that she might take a somewhat different approach from that of her predecessor. So far, the Commission's work has taken a moderate position. For example, under draft article 2, immunity ratione personae extends to heads of states, heads of government, and ministers of foreign affairs. A broader approach would have included other high level officials while a narrower approach would have limited immunity to just heads of state and government. The choice made in draft article 2 tracks the International Court of Justice's decision in the Arrest Warrant Case, which probably made this decision fairly straightforward for the Commission.

In wording that favors immunity, the draft articles definition of an act performed in an official capacity includes any act performed by a State official in the exercise of State authority, so that when individuals act in violation of international law, including international criminal law, they may nonetheless be acting in an official capacity. Our commentators examine this approach to the definition of official acts, as well as the issue of possible exceptions to immunity ratione materiae, which will be the topic of the next report of the special rapporteur. That report will also address procedural issues around immunity, a somewhat neglected but vitally

* Helen Strong Curry Chair in International Law and Director of the International Legal Studies Program at Vanderbilt University Law School.

Originally published online 14 December 2015.

${ }^{1}$ International Law Commission, Analytical Guide to the Work of the International Law Commission, Immunity of State officials from foreign criminal jurisdiction.

2 William S. Dodge, Foreign Official Immunity in the International Law Commission: The Meanings of "Official Capacity", 109 AJIL Unbound 156 (2015).

${ }^{3}$ Chimène I. Keitner, Horizontal Enforcement and the ILC's Proposed Draft Articles on the Immunity of State Officials from Foreign Criminal Jurisdiction, 109 AJIL Unbound 161 (2015)

${ }^{4}$ Roger O'Keefe, An 'International Crime" Exception to the Immunity of State Officials from Foreign Criminal Jurisdiction: Not Currently, Not Likely, 109 AJIL Unbound 167 (2015). 
important topic. My own work, in an article entitled Foreign Official Immunity: Invocation, Purpose, and Exceptions, ${ }^{5}$ explores some of these procedural issues.

Immunity is an important issue in its own right; justice and accountability for violations of international criminal law are obviously important values. But it is also part of a broader move to reframe sovereignty and international law itself in terms of individuals and human security. ${ }^{6}$ Doctrinally, immunity or restrictions on it are one corner of a potential transformation of international law which includes universal jurisdiction, international criminal law, responsibility to protect, and a re-orientation of the work of UN Security Council. Today, however, doctrinal setbacks, the apparent failure of intervention in Libya, difficulties implementing universal jurisdiction, and questionable support from states, all raise questions about whether this broader re-orientation of international law has been or will be fully successful. The values protected by immunity-sovereign equality of states, peaceful coexistence, the avoidance of biased or incorrect judgments by the national courts of foreign states-are of continued, if not growing, importance.

\section{Draft Articles Preliminarily Adopted by ILC by August 2015}

\section{Draft Article 1}

\section{Scope of the present draft articles}

1. The present draft articles apply to the immunity of State officials from the criminal jurisdiction of another State.

2. The present draft articles are without prejudice to the immunity from criminal jurisdiction enjoyed under special rules of international law, in particular by persons connected with diplomatic missions, consular posts, special missions, international organizations and military forces of a State.7

\section{Draft Article 2 \\ Definitions}

(e) A "state official" means any individual who represents the State or who exercises State functions.

(f) An "act performed in an official capacity" means any act performed by a State official in the exercise of State authority.

\footnotetext{
5 Ingrid B. Wuerth, Foreign Official Immunity: Invocation, Purpose, and Exceptions, SwISS REv. InT'L \& EuR. L. (2013).

${ }^{6}$ See, for example, Ruti Teitel, Humanity's Law (2013); and Anne Peters, Humanity as the $A$ and $\Omega$ of Sovereignty, 20 Eur. J. IN'T L. 513 (2009).
} 


\section{Draft Article 3}

Persons enjoying immunity ratione personae

Heads of State, Heads of Government and Ministers for Foreign Affairs enjoy immunity ratione personae from the exercise of foreign criminal jurisdiction.

\section{Draft Article 4}

\section{Scope of immunity ratione personae}

1. Heads of State, Heads of Government and Ministers for Foreign Affairs enjoy immunity ratione personae only during their term of office.

2. Such immunity ratione personae covers all acts performed, whether in a private or official capacity, by Heads of State, Heads of Government and Ministers for Foreign Affairs during or prior to their term of office.

3. The cessation of immunity ratione personae is without prejudice to the application of the rules of international law concerning immunity ratione materiae.

\section{Draft Article 5}

\section{Persons enjoying immunity ratione materiae}

State officials acting as such enjoy immunity rationae materiae from the exercise of foreign criminal jurisdiction.

Draft Article 6

\section{Scope of immunity ratione materiae}

1. State officials enjoy immunity ratione materiae only with respect to acts performed in an official capacity.

2. Immunity ratione materiae with respect to acts performed in an official capacity continues to subsist after the individuals concerned have ceased to be State officials.

3. Individuals who enjoyed immunity ratione personae in accordance with draft article 4, whose term of office has come to an end, continue to enjoy immunity with respect to acts performed in an official capacity during such term of office. 